tion on peripheral discrimination thresholds in single and multiple element displays. Acta Psychologica, 69, 129-155.

NeIsSER, U. (1967). Cognitive psychology. New York: AppletonCentury-Crofts.

Posner, M. I., \& CoHen, Y. (1984). Components of visual orienting. In H. Bouma \& D. G. Bouwhuis (Eds.), Attention and performance $X$ (pp. 531-555). Hillsdale, NJ: Erlbaum.

Posner, M. I., Walker, J. A., Friedrich, F. J., \& Rafal, R. D. (1984). Effects of parietal injury on covert orienting of attention. Journal of Neuroscience, 4, 1863-1874.
Tsal, Y. (1983). Movements of attention across the visual field. Journal of Experimental Psychology: Human Perception \& Performance, 9, 523-530.

Wolford, G., \& Chambers, L. (1983). Lateral masking as a function of spacing. Perception \& Psychophysics, 33, 129-138.

Yantis, S. (1988). On analog movements of visual attention. Perception \& Psychophysics, 43, 203-206.

(Manuscript received April 1, 1991.)

\title{
The Second International Conference on Music Perception and Cognition University of California, Los Angeles February 22-25, 1992
}

The Second International Conference on Music Perception and Cognition (2nd ICMPC) will be held, under the auspices of the Society for Music Perception and Cognition (SMPC), at the University of California, Los Angeles (UCLA) February 22-25, 1992. The Conference follows the highly successful first conference held in Kyoto, Japan, in October 1989. The 2nd ICMPC will provide an open forum for work in all areas of music perception, cognition, and related disciplines. There will be symposia of interest to a general audience and sessions of particular interest to specialists. Concerts and performance of all types of music, including non-Western, will be staged.

The conference welcomes a full range of research and scholarship, including experimental, theoretical, musicological, ethnomusicological, acoustical, physiological, and computational, which are directed toward the musical mind. In addition, performances of compositions that are based on these domains, or lecturerecitals including recorded tapes, are encouraged.

Abstracts of roughly 250 words should be submitted by September 30, 1991. Contributed papers are welcome. All papers should describe work that has not been presented at a conference or published in a journal. Proceedings will be published in consultation with the SMPC.

For further information, please contact Roger A. Kendall, 2nd ICMPC Secretariat, Department of Ethnomusicology and Systematic Musicology, 1642 Schoenberg Hall, UCLA, Los Angeles, CA 90024 (telephone, 213-206-6080; FAX, 213-206-6958). 